\title{
The Iron in the Posthole: Witchcraft, Women's Labor, and Spanish Folk Ritual at the Berry Site
}

Robin A. Beck

\begin{abstract}
Apotropaic devices-folk ritual objects and deposits intended to ward away witchcraft or ensorcellment-were often deliberately concealed near the vulnerable parts of a structure (doors, windows, hearths, and chimneys). Because such devices typically consisted of otherwise mundane materials, they can be difficult to identify in archaeological deposits. It is the unusual context of the deposit that alerts us to the potential of its apotropaic meaning and intent. Here, I discuss the social and spatial contexts of an iron jack plate fragment concealed near the doorway of a Spanish colonial kitchen at the Berry site. Berry, located in present-day western North Carolina, was the site of Fort San Juan de Joara (1566-1568), the first European settlement in the interior of what is now the United States. Recognizing the iron jack plate fragment as a potential apotropaic device opens a window onto Spanish male anxieties about women's labor, especially the domestic labor associated with food. Spaniards and other Europeans believed that "wild" women regularly used ensorcelled food to entrap or punish male victims. Nowhere were fears of ensorcelled food more pronounced than along the frontiers of colonial America, where indigenous women usually prepared meals for Spanish men as wives, servants, and concubines. [colonialism, witchcraft, gender, food, folk ritual, the Berry site, colonial America]
\end{abstract}

RESUMEN Los objetos apotropaicos-objetos y depósitos rituales populares con el propósito de protegerse contra hechicería o encantamiento-fueron a menudo deliberadamente ocultos cerca de las partes vulnerables de una estructura (puertas, ventanas, fosos del fuego, y chimeneas). Desde que tales objetos típicamente consistieron de materiales por lo demás mundanos, pueden ser difíciles de identificar en depósitos arqueológicos. Es el contexto inusual del depósito lo que nos alerta del potencial de su significado e intento apotropaico. Aquí, discuto los contextos sociales y espaciales de un fragmento de una placa de hierro de una armadura oculto cerca de la entrada de una cocina colonial española en el sitio Berry. Berry, ubicado en la parte Oeste de la actual Carolina del Norte, fue el sitio del Fuerte San Juan de Joara (1566-1568), el primer asentamiento europeo en el interior de lo que es ahora los Estados Unidos. Reconociendo el fragmento de la placa de hierro de una armadura como un potencial objeto apotropaico abre una ventana hacia las ansiedades de los hombres españoles acerca del trabajo de la mujer, especialmente el trabajo doméstico asociado con la comida. Los españoles y otros europeos creyeron que las mujeres "salvajes" regularmente usaban comida "encantada" para atrapar o castigar a las victimas hombres. En ninguna parte fueron los miedos de comida encantada más pronunciados que a lo largo de la frontera de la América colonial, donde mujeres indígenas usualmente prepararon alimentos para los hombres españoles como esposas, sirvientas, y concubinas. [colonialismo, brujería, género, comida, ritual popular, el sitio Berry, América colonial] 
$\mathrm{O}$ $\mathrm{n}$ the final day of our 2007 field season, my colleagues and I were excavating postholes in Structure 5 at the Berry site, situated on a tributary of the upper Catawba River in present-day Burke County, North Carolina. As we hurried to finish our work, a Bobcat bulldozer sat nearby, engine thrumming, waiting to return our backdirt to the excavation area. Structure 5 was one of five buildings that we had discovered at the northern end of the Berry site a few years earlier, all of which appeared to have been burned to the ground in a single event. We identified this cluster of five burned buildings and associated features as a domestic compound that housed 30 Spanish soldiers at Fort San Juan, a garrison founded by Juan Pardo at the ancestral Catawba Indian town of Joara in December 1566 (e.g., Beck et al. 2006; Beck et al. 2016). We had just begun the excavation of several exterior posts along the southeastern wall of Structure 5 when a member of the crew, Cricket Hefner, shouted out, "Hey guys, there's a piece of metal in this one!" The rest of us quickly gathered around Cricket, and with a precise flick of her brush, she removed a bit of soil from the top of her posthole. Sure enough, we could see the edge of a rusted object, jammed into the posthole fill right next to the fire-blackened remains of the post itself.

How, then, did this iron artifact, later identified as a relatively large fragment of jack plate armor (Figure 1), end up in the posthole? My aim in this article is to offer an interpretation of the unusual deposit, an object and a context that together may illuminate increasing tensions between settler and native communities, culminating in the destruction of Fort San Juan in the spring of 1568. Explaining the iron in the posthole will require a discussion of apotropaic protections, especially of those protections that Chris Manning (2014b:52) refers to as ritual concealments - "a deposit of one or more artifacts deliberately hidden within the structure of a building as part of a magico-religious or secular folk ritual." While archaeologists have yet to identify or report other ritual concealments from early Spanish colonial sites, both the historical and archaeological contexts of the jack plate offer broad support for such an explanation. To make this case, I first establish the historical setting of Fort San Juan, situating this isolated garrison in relation to contemporaneous European fears of women's labor-particularly regarding food preparation - and the potential manifestation of women's power through culinary witchcraft or ensorcellment. Such concerns helped structure colonial labor regimes throughout the Spanish Americas, where indigenous, African, and mulatto women performing household labor had few sanctioned routes to social power.

After setting the historical context, I return to the Berry site and to archaeological excavations in Structure 5. I present evidence suggesting that this building served as a formal kitchen or cocina in the later months of the Spanish occupation and that the iron jack plate was deliberately planted in a posthole near its door as a ritual concealment, one intended to shield the structure - as well

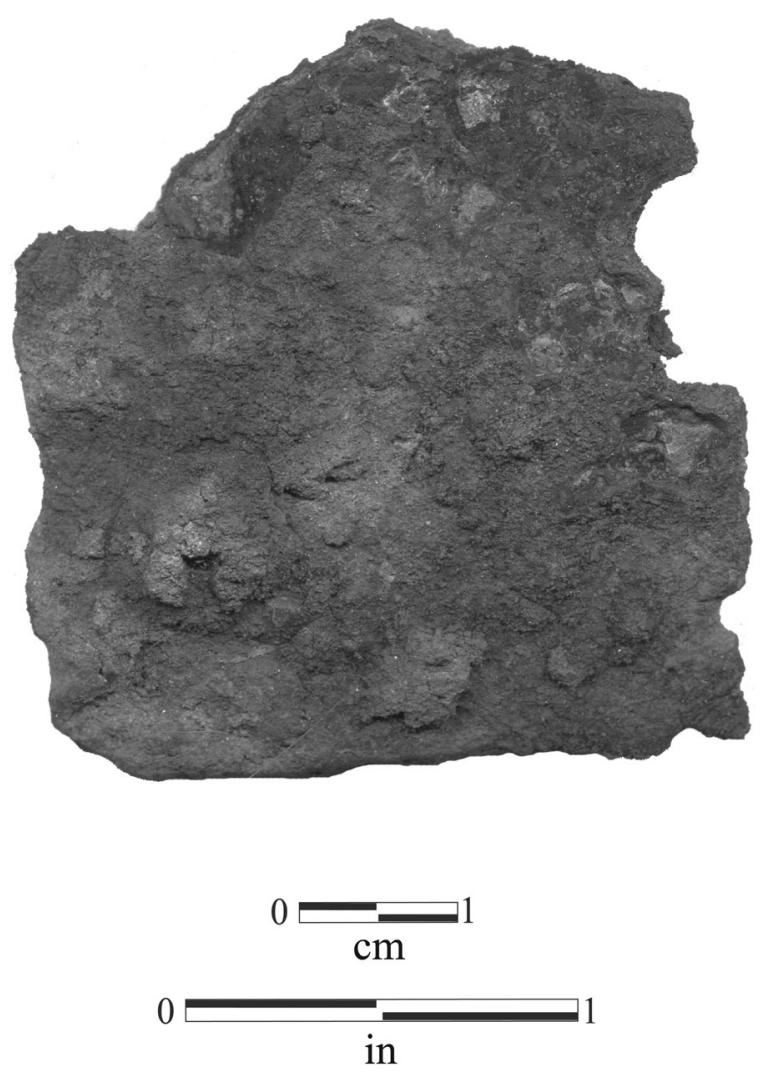

FIGURE 1. Iron jack plate from Structure 5 (catalogue \#042-1877).

as the meals that Indian women prepared within - from the threat of ensorcellment. While archeologists have made remarkable progress documenting the persistence of such apotropaic concealments in African American households and communities, until recently there has been far less inclination to recognize the important role that folk ritual practices continued to play within communities of European immigrants (Fennell 2000:287-290; Manning 2014a:3). Not only is the lapse curiously ahistorical, but it also perpetuates the association of magic and superstition with subaltern classes and social groups. In explaining the iron in the posthole, I aim to show not only that such beliefs and practices accompanied conquistadors across the Atlantic but also that these preoccupations about magic and witchcraft, particularly as they shaped gender relations and regimes of labor, pervaded the colonial experience for natives and newcomers alike.

\section{MUNDANE MAGIC: RITUAL CONCEALMENTS IN ARCHAEOLOGY}

For as long as people have lived in fear of witchcraft and its various ensorcellments, they have also put their faith in the efficacy of material protections to keep these powers at bay. Such protections, referred to collectively as apotropaic magic (from the Greek term apotrepo, "to ward off" [e.g., Borić 2002:60]), are most prominent in objects of personal adornment such as amulets and jewelry, in works of art, and 
in architecture. Architectural safeguards include the painting or engraving of esoteric symbols above entryways and near hearths, the display of iron objects such as horseshoes above doors, and the use of gargoyles and other grotesque figures. Yet apotropaic precautions did not require visibility to be effective. Just as often, such devices were deliberately concealed from view within houses and other standing structures, usually in vulnerable areas like doorways, chimneys, and hearths. Objects believed to have apotropaic qualities in European folk traditions and deposited in such ritual concealments include witch bottles (which themselves may contain urine, pins, needles, nails, and other objects); leather boots and shoes; articles of clothing such as hats, doublets, and trousers; desiccated cats; horse skulls; and implements of iron (Eastop 2006, 2007; Fennell 2014; Herva 2009; Herva and Ylimaunu 2009; Hoggard 2004; Hukantaival 2013; Lucas 2014; Manning 2012, 2014a, 2014b; Merrifield 1987; Ruppel et al. 2003). What is most compelling about these deposits, perhaps, is their everyday, quotidian character. Why were such profane things invested with the power to ward off malevolent forces and beings?

This question inevitably brings us to the problem of object agency. Alfred Gell (1992, 1998), in particular, has considered apotropaic effects in his anthropological theory of visual art. He views the apotropaic elements of art - from Celtic knotwork to Vermeer's Lacemaker to the elaborately carved and painted prow-board of a Trobriand Islander's canoe - as constituting "technologies of enchantment" (Gell 1998). Gell's approach to object agency makes a significant contrast between the primary or intentional agency of conscious actors and the secondary agency of objects, which do not cause happenings through their own acts of will but, rather, represent "objective embodiments of the power or capacity to will their use" (Gell 1998:21). So far, so good. But it is difficult to extend his ideas about the apotropaic qualities of art to mundane objects such as old shoes, hats, and bits of iron (Gilchrist 2012:212). Art derives enchanting power from a virtuoso mastery of technique that is "explicable only in magical terms" (Gell 1992:46). This technology of enchantment, then, depends on the enchantment of technology, "the power that technical processes have of casting a spell over us so that we see the real world in an enchanted form" (Gell 1992:44). Apotropaic patterns like those in Celtic knotwork, for example, render demons harmless by distraction, drawing them into elegant, repetitive loops and coils and trapping them there (Gell 1998:84).

Whatever agency we accord to those mundane, everyday objects typically recovered from ritual concealments, it must operate differently from that which Gell accords to art. First, there is little focus on technical proficiency among the objects in such deposits. Moreover, the aggregate deposits are deliberately concealed from view. In place of an agency that derives from the power to enchant, the agency of ritual concealments may derive explicitly from their mundane qualities, which instead entail the power to repulse or deflect. This is a latent power intrinsic to the objects themselves - or to the assemblage of objects - that is only invoked or entreated through verbal cue (spell or incantation). Ritual concealments therefore satisfy Gell's criteria for secondary agency, because an act of conscious (primary) agency is needed to unleash their potential for action, through which intervention they become, to return to Gell's (1998:21) phrase, "objective embodiments of the power or capacity to will their use." This brings us to another significant distinction between technologies of (apotropaic) enchantment and ritual concealments. Technologies of enchantment reinforce dominant religious ideologies: they are often displayed in publicly visible contexts, and the technical mastery evident in their crafting and production is a significant investment of social resources. The private magic of ritual concealment, however, occurs in the margins of prevailing ideologies; to borrow Gell's linguistic inversion, ritual concealments objectify concealed rituals. Thus, ritual concealments must not be confused with votive offerings, foundational deposits, and similar acts that likewise remove objects from circulation but do so in publicly sanctioned ritual. This is key to understanding such concealments as folk practice. As Christopher Fennell observes,

If religions represent attempts at all-encompassing accounts, what
then are instances of magic, superstition, and folk belief? A gen-
eral answer is that they represent the personal observances of
a religion that was once dominant, but was later subjugated by
another belief system in a past social competition. These per-
sonal observances were once part of a full-spectrum religion, but
the public and sodality-oriented components of that belief sys-
tem were suppressed and pushed from the public stage by another
religion promoted by a new, socially dominant group. [2014:196]

Because they are marginal to prevailing, public ideologies, folk ritual practices tend to be poorly documented in contemporary text (Manning 2014a:3). Archaeology, then, can potentially offer an unparalleled window onto the material evidence of ritual concealments. Yet much of the evidence on these practices acquired to date has come from standing structures, collected through preservation and renovation activities. Even when possible concealments are encountered during excavations, they are typically not recognized as such (Gilchrist 2012:230). Archaeologists have recently developed robust methodologies for interpreting other kinds of ritual deposits, including votive offerings and dedicated objects (Osborne 2004); the deliberate dismantling and closing of architecture (Walker and Lucero 2000); and categories of destroyed objects often associated with the persecution of witches (Walker 1998, 2008). What these approaches all have in common is a focus on the significance of context, and it is context that should alert us to the potential presence of ritual concealments - specifically the deliberate deposition of mundane materials in unexpected places. We can now turn back to the case at hand: the iron jack plate from Fort San Juan. Before delving into the archaeology of the Berry site, however, I need to situate the Pardo expeditions in the broader context of women's labor and its role in Spanish colonialism. 


\section{THE IMPERILED CONQUISTADOR}

In the 16 th and 17 th centuries, native communities in the New World became entangled with Spanish settler groups composed primarily or exclusively of adult men. Kathleen Deagan observes that native women in such contexts were "active culture brokers and agents of a multicultural household practice, whether as wives, servants, or concubines" (2008:877; see also Voss 2008). During this early colonial period, Spanish men carried particular fears and fixations about the spiritual dangers of women's household labor with them to the Americas. In 1486, two German clergymen, Heinrich Kramer and James Springer (though there is debate as to the extent of Springer's involvement), had written the now infamous Malleus Maleficarum (lit., The Hammer of Witches [1948]). Few works on witchcraft were as popular and influential as the Maleficarum, which went through no less than 30 editions by 1669 (e.g., Lewis 2003:223, n. 42), and few were as explicit in linking the practice of witchcraft to the carnal sins of women (Lewis 2003:111-112; Krögel 2011:148-149; Silverblatt 1987:160-161). The Maleficarum and similar texts gave voice and legitimacy to a profound misogyny and fueled the witch hunts that burned across so much of Europe in the decades that followed. In Spain, however, Inquisition authorities treated witchcraft charges more leniently, "a sign of ignorance rather than heresy" (Behar 1989:182). In contrast to those rural visions of demonic conspiracy prevalent in northern Europe, Ruth Behar notes that

the love magic and sexual witchcraft common in Castile and southern Spain (as well as in much of Italy) was decidedly urban, and more concerned .... with dyadic domestic and erotic relationships. Unlike the northern European image of the witch as an old, ugly, poor woman, the women involved with witchcraft in Castile were usually young unmarried women, widows, wives abandoned by their husbands, or women living in casual unions with men; they were maids and servants, sometimes prostitutes, and in southern Spain often moriscas, women of mixed Spanish and Moorish blood. [1989:182-183, italics in original]

Spaniards and other Europeans believed that such women regularly used ensorcelled food to ensnare male victims (Behar 1989:179-180; Krögel 2011:148-153; Lewis 2003:110). Fears of what Allison Krögel (2011:148) refers to as "culinary witchcraft" were pervasive both in Spain and in its New World colonies. In Spanish households, women performed and controlled the labor of food preparation, making food and related activities one of the few domains of daily practice in which women could exercise social power. Such power was a source of danger, however, because women could use it for ill as well as for good (Lewis 2003:64). Behar notes, for example, that

women made men "eat" their witchcraft . . . The belief that food could be used to harm rather than nurture gave women a very specific and real power that could serve as an important defense against abusive male dominance. And perhaps, too, women's serving of ensorcelled food to men was another kind of reversal, sexual rather than social: a way for women to penetrate men's bodies. [1989:180]
This particular kind of magic was so feared because it could be used to rob the unsuspecting man of his health — or, worse, the essence of his masculinity. The most marginalized women in society were especially dangerous, because witchcraft provided them a potent weapon for avenging wrongs both real and imagined (Maxwell-Stuart 2001:91). Throughout the Spanish Americas, native women were perhaps the most marginalized social group of all.

Church authorities believed that the spiritual essence of pacified Indians, men and women alike, was that of the child - if not even feminine. Like women, Indians were thought to be weak willed, imperfect, and prone to sloth; they were all "incomplete men" according to royal chaplain Juan Gínes de Sepúlveda (Lewis 2003:59). Moreover, Indians were unable to inhibit their carnal appetites and thus embraced the same sorts of abominations that Kramer and Springer had linked to women and witches in the Maleficarum. Just as "wild" women-prostitutes, widows, and those living with men outside of marriage-were considered most likely to perform witchcraft, so too were "wild" Indians - those who lived farthest from colonial centersmost feared. In colonial Mexico, the nomadic Chichimec Indians who roamed the colony's northern frontiers were feared and despised above all others (Behar 1987:116-118; Lewis 2003:28, 108-109). For nearly half a century, from the discovery of silver in 1546 near what would become the city of Zacatecas until 1590, Spanish settlers and miners waged a long and brutal war to pacify the Chichimec, a loosely allied confederation of four distinct ethnic groups. These Chichimec were "expert archers, brave warriors, and cruel victors, who had a reputation for scalping, dismembering, and eating many of their victims" (Behar 1987:116). It was also to these peoples that Church authorities imputed the most dangerous kinds of witchcraft (Lewis 2008:108). Indeed, Spanish anxiety was deep enough that in 1566 Captain Juan Pardo was dispatched from the Atlantic Coast to forge a northern route to Zacatecas that might circumvent this Chichimec threat (Hudson 1990:130).

Juan Pardo's mission took place in the context of Spain's repeated failures to successfullycolonize what is now the southeastern United States. Finally, in 1565-1566, Pedro Menéndez de Avilés planted two new settlements along the southern Atlantic Coast: St. Augustine, established September 1565 in Florida, and Santa Elena, founded April 1566 on present Parris Island, South Carolina. The latter settlement, Santa Elena, was to be the principal town of Menéndez's colonial aspirations (e.g., Hoffman 1990; Hudson 1990; Lyon 1976, 1984). When Philip II learned of this news, he ordered reinforcements for the colony. In July 1566, Pardo disembarked at Santa Elena with a company of 250 soldiers and quickly set his men to fortifying the settlement. Because the Santa Elena colony was not prepared to feed this large contingent of men for very long, however, Menéndez ordered Pardo to prepare half of his army for an expedition into the interior lands that lay behind the Atlantic coast. Pardo's task was to explore this region, to claim the land for 


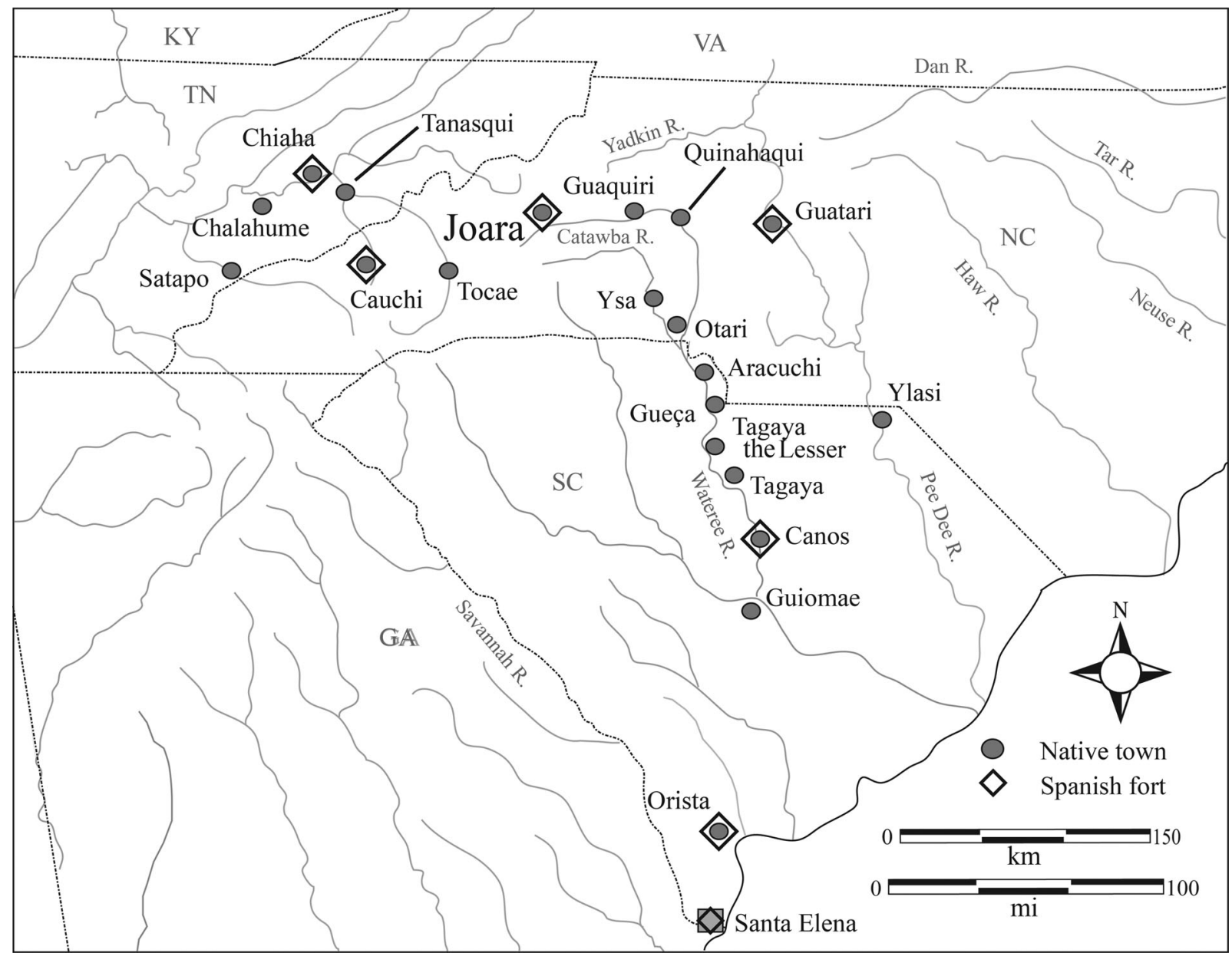

FIGURE 2. Towns visited by Juan Pardo's second expedition, 1567-1568.

Spain while pacifying local peoples, and to forge an overland path from Santa Elena to the silver mines in Zacatecas. Pardo departed with 125 men on December 1, 1566.

Later that month, after traversing the Carolina Piedmont along the Wateree and Catawba rivers, Pardo and his soldiers arrived at Joara (Figure 2), a large native town situated in the upper Catawba Valley near the eastern edge of the Appalachian Mountains (e.g., DePratter et al. 1983; Hudson 1990). The leader of Joara, referred to in the accounts as Joara Mico (mico was a native term for regional or multicommunity chief [Anderson 1994; Hudson 1990]), held some authority over towns on the upper Catawba River and its tributaries (Beck 2013:85). Pardo renamed this town Cuenca, after his own native city in Spain. At Joara, he built a fort, christened San Juan, which he garrisoned with 30 men. Although previous expeditions into the interior had either founded seasonal encampments or had temporarily occupied native towns, Pardo explicitly established Fort San Juan to expand Santa Elena's reach into the northern frontiers of La Florida. In so doing, he founded the earliest European settlement in the interior of what is now the United States (Beck et al. 2006). During the course of his second expedition in 1567, Pardo would go on to establish five more garrisons between the Atlantic Coast and present eastern Tennessee, yet Fort San Juan was to be the center of his imperial designs.

The soldiers of Fort San Juan were garrisoned at Joara as part of a much larger mission to secure Spanish interests from the most violent and spiritually dangerous native peoples known to New Spain. What was more, Pardo and his men had good reason to believe that they were closer to the Chichimec heartland than was, in fact, the case. On September 1, 1567, as Pardo left from Santa Elena at the beginning of his second expedition, he carried a written order from Menéndez stating "you will take the road which seems to you most convenient and direct to go to Zacatecas and the mines of San Martín" (Bandera 1990:256). Incredibly, these same commands state, a bit further on, that "You will try to be back in this fort of San Felipe [at Santa Elena] in the course of the month of March [1568] if it is possible" (Bandera 1990:257). Thus, Pardo's command was to travel overland from Santa Elena to Zacatecas - and back - in just seven months. Such an order makes sense only in the context of Spanish misconceptions about the continent's vast interior. In the 16th century, Europeans had little geographic understanding of those lands north of New Spain and inland beyond the Atlantic, believing this enormous expanse to be much narrower than it actually is 
(Hudson 1990:171, figure 41; Lewis and Loomie 1953:19, plate III).

Shortly after Pardo returned to Santa Elena at the end of the first expedition, his officer at Fort San Juan, Hernando Moyano, destroyed the village of "a cacique ... named Chisca" (Martinez 1990:320). Moyano sent a message to Pardo reporting his actions, suggesting that he could press farther on beyond the mountains if Pardo commanded. But before the captain's response arrived, another "cacique of the mountains sent a threat to the sergeant saying that he would come and eat them and a dog the sergeant had" (Martinez 1990:320). Moyano and his force then marched into the mountains and destroyed the village of this cacique, as well. The Spaniards took an unknown number of women from the two destroyed villages, at least eight of whom went to Santa Elena as slaves before being released in December 1567 (Hudson 1990:176). For those soldiers stationed at Fort San Juan, the mountain cacique's vow to eat them all_as well as Moyano's dog, probably a large mastiffmight have confirmed that the Chichimec were close. Any women taken captive from such a people, though perhaps more easily coerced in their captivity than local women from Joara, might have posed an existential threat in the very fact of their abasement.

During most of the 18 months that Spanish soldiers lived at Joara, amicable relations held between the people of this town and their Spanish guests. For example, as Pardo readied to leave Joara during the second expedition, he commanded his ensign, Alberto Escudero de Villamar, to "judge and have a care of the conservation of the friendship of the caciques and Indians of all the land" (Bandera 1990:278). Yet in the months that followed, relations between Fort San Juan and the town of Joara took a calamitous turn for the worse. By May 1568, word reached Santa Elena that Indians had attacked all six of Pardo's interior garrisons, including Fort San Juan, and that all were lost (Hudson 1990:176). Several factors must have played a role in this decisive action, but two stand out: (1) the soldiers' demands for food and (2) their relations - whether these were coercive or consensual is unclear - with Indian women (Hudson 1990:176). Before leaving Fort Santiago de Guatari, for example, Pardo had ordered its officers "that no one should dare bring any woman into the fort at night ... under pain of being severely punished" (Bandera 1990:285). In the end, 130 soldiers and all of Pardo's isolated forts were lost and with them Spain's last attempt to colonize the northern frontiers of La Florida. More than a century would pass before the next Europeans are known to have penetrated this far into the southern Appalachians.

\section{A COLONIAL KITCHEN AT THE BERRY SITE}

Archaeological and documentary evidence (e.g., Beck 1997; Beck et al. 2006; Worth 2016) indicates that both Joara and Fort San Juan were located at the Berry site (31BK22). Berry is located on Upper Creek, a tributary of the Catawba River, in what is now Burke County, North Carolina (Figure 3).
Today the site covers 4.5 hectares and is situated along the easternmost margin of a 75-hectare alluvial floodplain. My colleagues and I have directed fieldwork at Berry for 18 seasons, focusing our efforts on a 0.5 -hectare part of the site at which we have recovered a significant assemblage of 16th-century Spanish ceramics and hardware, together with personal and military artifacts (Beck et al. 2006; Rodning et al. 2016). This area - occupying the northernmost margin of the site - is associated with a cluster of five burned structures, dozens of pit features, and hundreds of postholes that we refer to collectively as the Spanish compound (Figure 3); these remains are the material footprint of Pardo's Cuenca. In 2013, we identified the dry moat of Fort San Juan about 20 meters south of the compound, indicating that the fort occupied a position between this domestic zone and the town of Joara. None of Pardo's other forts have yet been discovered.

Excavations in two of these buildings, Structures 1 and 5 , have provided a broad range of data on construction techniques and practices (Beck et al. 2016; Newsom 2016). Structure 1, the larger of the two, measured about 7.5 meters on a side $\left(56 \mathrm{~m}^{2}\right)$ and was one of four structures built in semi-subterranean basins. Such basins are typical of Late Mississippian architecture across the southern Appalachians (e.g., Hally 2008; Lacquement 2007); indeed, the form of Structure 1 was typical of indigenous-style architecture across the region. It contained a central hearth, four large and deeply placed interior support posts, and a well-defined entryway with exterior wall trenches located on the western corner of the structure.

Structure 5, measuring 49 square meters, was less typical of native architecture. Although its central hearth was similar to that of Structure 1, it was not built in a basin, its entry area was not marked by trenches, and its four central posts were set into surprisingly shallow postholes such that they offered insufficient support for the structure's roof; two additional interior posts were later added to stabilize the building (Figure 4). Compounding this structure's relative instability was the fact that many of its exterior posts were set in postholes that were likely dug with metal shovels such that the holes were much wider than the posts themselves (Beck et al. 2016:102); in Structure 1, however, the wall and center posts were set into postholes excavated by digging sticks and by ramming the posts into place, creating postholes with about the same diameter as the posts. Both buildings contained large quantities of carbonized wooden posts and timbers, many of which had been harvested and prepared using distinctly European carpentry techniques and metal tools such as adzes, axes, and cross-cut saws - tools that were listed among the supplies carried by members of the Pardo expedition (Newsom 2016). Finally, both structures, as well as the three that remain unexcavated, burned at the same time. There is no evidence that any were ever rebuilt.

The Spanish compound had two distinct periods of construction activity. During the first phase, three buildingsStructures 1, 3, and 4 were constructed in a slight arc 


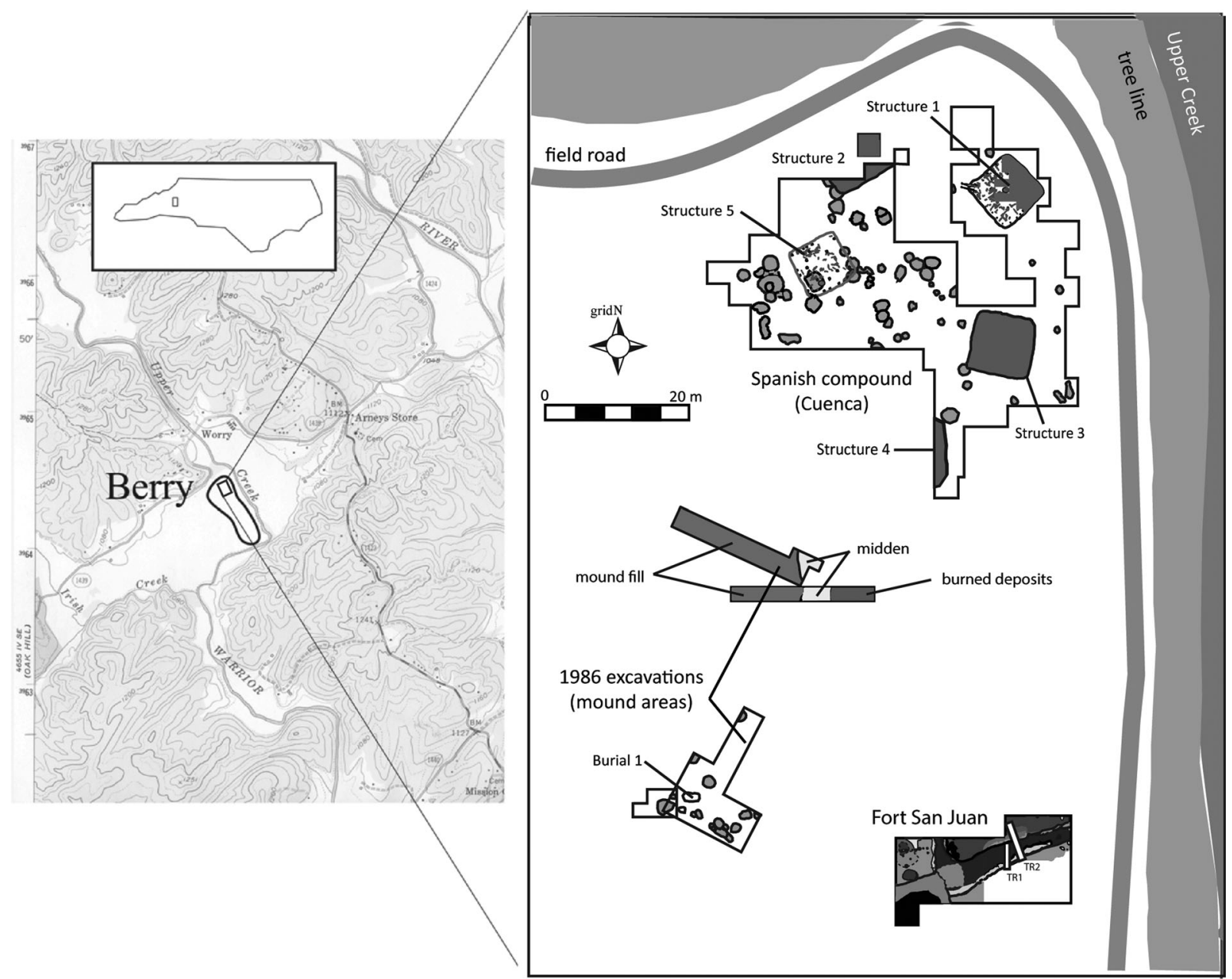

FIGURE 3. Berry site excavations, 1986-2013, indicating Spanish compound, mound areas, and Fort San Juan moat. Note that north arrow on this and all subsequent maps indicates grid north; the 1986 excavations are oriented toward magnetic north.

along the northern edge of the site (Figure 5). This phase likely coincides with Pardo's arrival at Joara in December 1566. The central pit features were dug during this first construction phase, when Structures 1, 3, and 4 were built; the pits were probably used for processing daub while the buildings were under construction, after which they were filled with refuse. Feature 76, a circular hearth measuring 66 centimeters in diameter, was located along the eastern edge of the central pits and may have served as an openair kitchen during the initial occupation. During the second phase of occupation (Figure 6), Structures 2 and 5 were built together along the same axis 15 to 20 meters west of the first structures; each of the two new buildings intrudes into the central features, establishing the temporal priority of the latter. Structure 2 was built in a basin like those of Structures 1, 3, and 4. Structure 5 was thus an anomaly. Its physical characteristics and spatial location suggest that it may have served as a formal cocina (kitchen) throughout the compound's second phase of occupation, replacing the informal kitchen associated with Feature 76 (Beck et al. 2016:139).

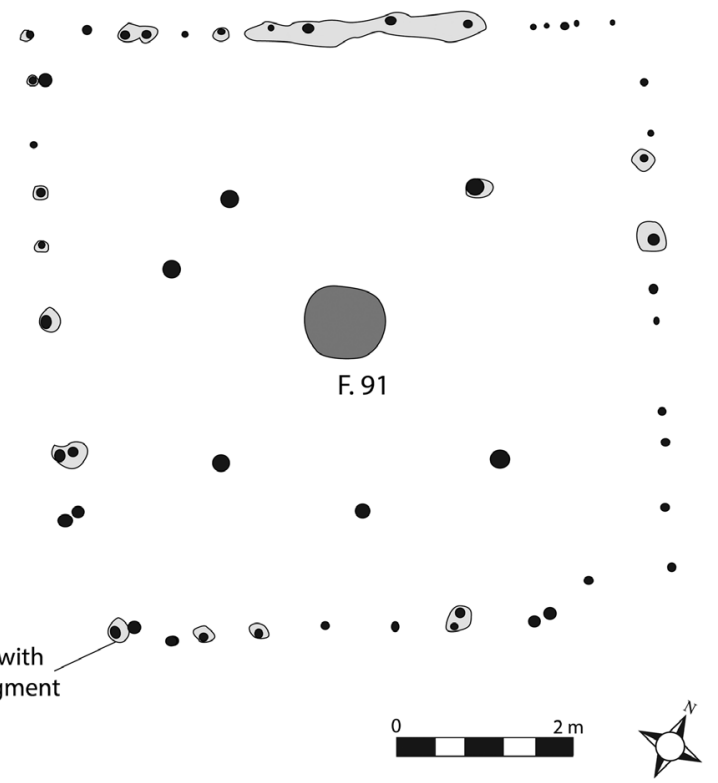

FIGURE 4. Plan map of Structure 5 at top of subsoil, showing posthole distribution. 


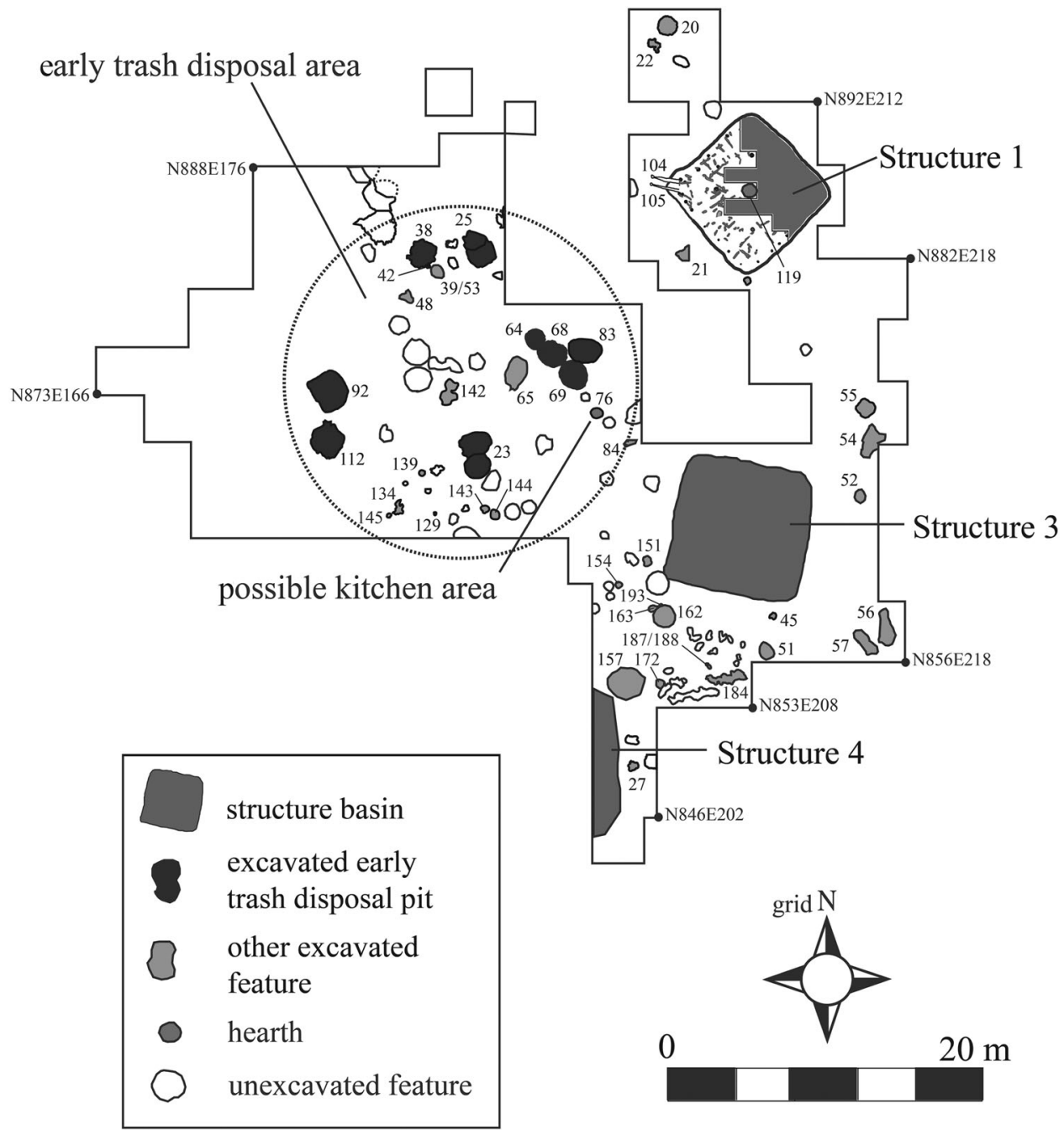

FIGURE 5. Plan map of Spanish compound, first-phase buildings and features with possible kitchen indicated.

No obvious kitchens, or even well-defined house lots, have yet been reported at 16th-century St. Augustine. Deagan (1985:13), though, observes that a wattle and daub structure from the Trinity Episcopal site may have served as a kitchen, due both to the presence of a nearby well and to the large amount of food-processing debris. At Santa Elena, too, no definite kitchens have been identified. Some of the richest data on Spanish colonial kitchens comes from the de la Cruz site in 18th-century St. Augustine; while it is far removed in time from the Spanish compound at the Berry site, it does offer some suggestive comparative evidence. The de la Cruz site contained three buildings, two of which, both built along the street, have been identified as houses (Deagan 1983:109). The third structure - built behind the other two - was smaller than the houses and was the only area of the lot with primary sheet midden. There was also a concentration of trash-filled pits around the structure (Deagan 1983:107-108). Moreover, it was close to the de la Cruz well, it was built on top of earlier pits associated with cooking activity, and all of the lot's nonceramic food-processing wares were found in its immediate vicinity
(Deagan 1983:109-111). In general, Deagan (1983:77-78) links cocinas with the St. Augustine pattern of refuse disposal, noting that trash pits were located "away from the house structure ... with the heaviest concentrations of refuse in the vicinity of wells and the kitchen.”

Turning to the Franciscan missions, royal ordinances required mission complexes to have a church, a convento to house its priests, and a self-contained cocina, all of which were arranged around a central plaza (Jones and Shapiro 1990:504; Weisman 1992:6). The best documented of the mission cocinas was excavated at Santa Catalina de Guale on St. Catherine's Island (Thomas 1991:117). This kitchen was located 20 meters north of the convento (with which it was aligned) and measured 4.5 meters by 6 meters. The structure was enclosed on three sides by wattle and daub walls; the fourth side, facing the well, was open. Squared-off pine posts set in pits supported the walls, and a hearth was located near the center of the structure. Midden refuse deposits had accumulated in large features close by that may have begun as daub processing pits. A probable kitchen has also been reported at the Harrison Homestead site on Amelia Island, 


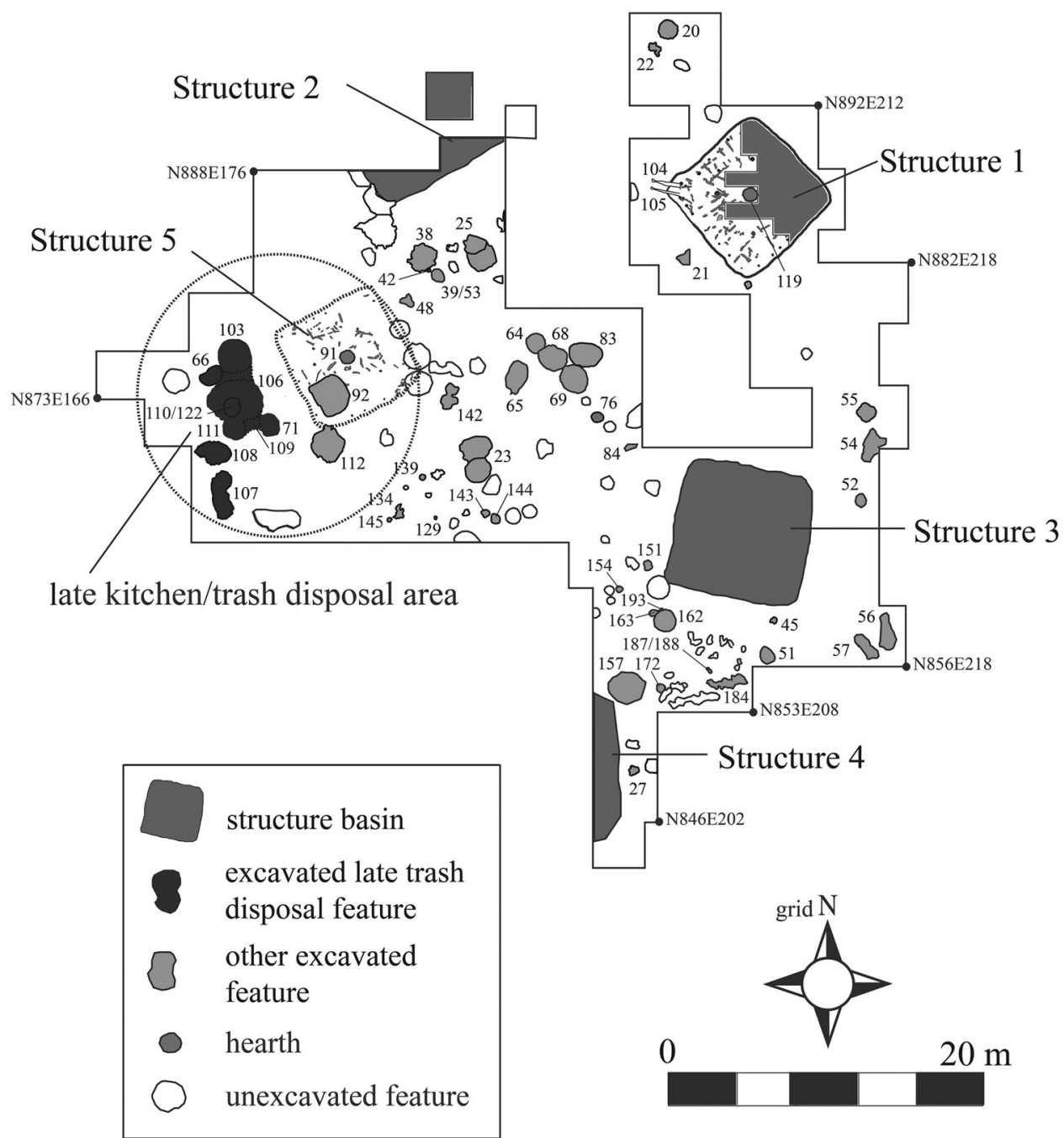

FIGURE 6. Plan map of Spanish compound, second-phase buildings and features with possible kitchen indicated.

Florida, where Santa Catalina de Guale moved in 1680 after the St. Catherine's mission site was abandoned (Saunders 1991:126). This rectangular building measured 6 meters by 3 meters and was located northwest of the convento, with which it also shared an alignment (Saunders 1991:128, 132). As with the St. Catherine's mission kitchen, it was open on one or more sides and formed a ramada. Saunders observes that "such a light structure associated with a midden was consistent with a kitchen" (1991:132).

None of these structures, whether those in town or mission settings, is an exact match for Structure 5 at the Berry site, particularly in the details of the architecture. This is not unexpected given the different cultural and temporal contexts that separate an early frontier garrison like Fort San Juan from later towns and missions. Yet there is significant variability in the architecture of these later town and mission cocinas, too. The point of this comparison, then, is not to match the architectural details of Structure 5 to these identified cocinas but, rather, to recognize the broader trends and patterns such that we might identify kitchens in different sorts of colonial settings, and here the exercise is illuminating. While as yet there is no evidence of a well near Structure 5-or anywhere else at the Berry site - this building otherwise had much in common with those referred to as cocinas elsewhere. It was flimsy or lightly built in relation to other buildings in the Spanish compound, and although it was enclosed on four sides, an open plan such as that of the two Santa Catalina de Guale cocinas would not have been practical at the Berry site given the colder winter climate so near the Appalachian Mountains.

More importantly - and unique to the compound's buildings - Structure 5 was adjacent to trash pits and a large midden, the only such deposit identified in the compound area. Analysis of nonstructure postholes in the compound suggests that two screens partially enclosed Structure 5 on three sides (Johgart 2011:39). One of the two screens might have offered the structure a bit of respite against the odors, insects, and rodents likely associated with the midden and refuse pits just to its west (Figure 7). The other screen may have facilitated the orderly movement of bodies toward and away from the structure at mealtimes. Together, the location of both screens strongly suggests that 


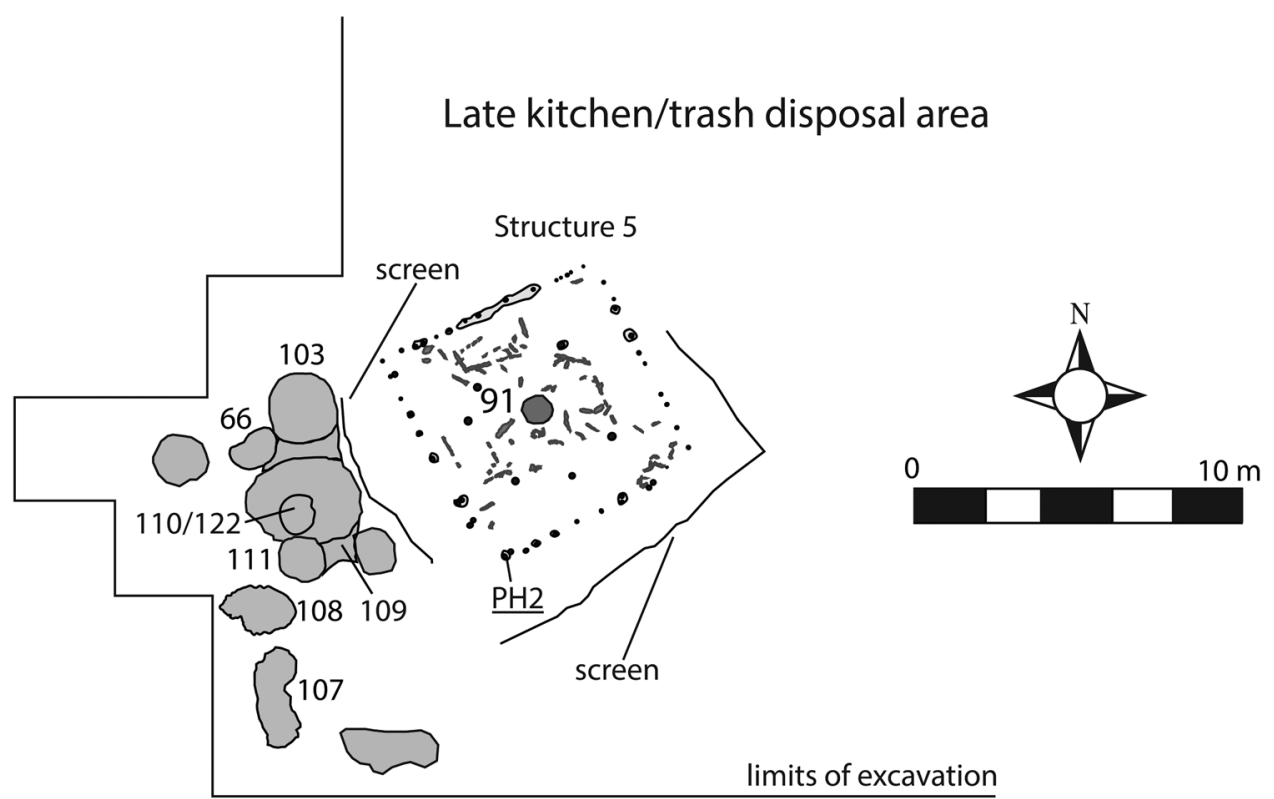

FIGURE 7. Plan map of Structure 5 and surrounding features, indicating location of screens.

the entry to Structure 5 was on its southern corner, giving easy access to the midden and pits during times of trash disposal.

Plant food remains - especially maize, nuts, and fruits such as grapes and maypops - were ubiquitous in Structure 5 , though the low overall density (relative to the features and the midden) suggests that it was regularly swept clean (Fritz 2016:240). Microartifact evidence also suggests that meat preparation took place inside Structure 5. Bone was poorly preserved in macroartifact samples (Lapham 2016:283), but several units in Structure 5 (21, 30, 38, 43, 46, and 47) did have high bone counts $(>100)$ in microartifact samples. Significantly, all of the bone in these samples was calcined (Beck et al. 2016:142). The presence of this burned bone cannot be explained by the fire that destroyed the building. Rather, it indicates that cooking was an important activity in Structure 5. Moreover, those units with the most bone $(21,30,38,46$, and 47) form a contiguous area east of the hearth, suggesting that this was a zone associated with meatprocessing activities. Finally, interpreting Structure 5 as a kitchen explains the steelyard scale hook recovered near the northeast corner of the building. Spanish soldiers received rations in specified quantities, usually as part of a comrade group. This scale might thus have been an important piece of equipment for the kitchen, ensuring that each group received its allotted amount of food.

\section{THE IRON IN THE POSTHOLE}

Who, then, was cooking food and preparing meals in Structure 5? While Pardo's soldiers were certainly capable of preparing their own meals, ethnohistorical and ethnobotanical evidence suggests that women prepared most of the dishes consumed in the Spanish compound. In Spanish colonies across La Florida and the Caribbean, women — whether as wives, servants, or slaves, and whether of Spanish, Indian, African, or mestiza descent — were responsible for kitchen labor (e.g., Deagan 1983:104-105, 271; McEwen 1991:55; Voss 2008:874). This is consistent with evidence from the Spanish compound, where archaeological remains of maizeand nut-based dishes differ little from foods identified in non-Spanish contexts at Berry and at contemporaneous sites across the region (Fritz 2016). Native women, that is, were preparing the same kinds of dishes for these soldiers as they were for their own families. Most of the women performing kitchen labor within the Spanish compound, especially during the early occupation phase, likely had homes nearby in Joara, but this may have changed over the course of the occupation. Specifically, archaeological evidence suggests that the labor of local women might have become less important than the labor of women taken captive during Moyano's two mountain forays.

Feature 112 was a large, circular pit, nearly 2 meters in diameter and 80 centimeters deep, located just outside the southwest corner of Structure 5. It was unusual both for its extraordinary quantity of hickory nut remains, associated perhaps with the preparation of kunuchee, a traditional Cherokee hickory nut soup (Fritz 2016), and for its unique assemblage of Pisgah-style pottery. The core of the Pisgah phase is located in the Appalachian Summit north and west of Berry, and its ceramics are different from those of the local Burke phase (Beck and Moore 2002; Moore 2002). Charles Hudson (1990:91) observes that the Chisca peoples were probably the bearers of Pisgah culture. Sherds from no fewer than eight Pisgah-style ceramic vessels were recovered from the fill of Feature 112, and because Pisgah towns were almost certainly among those devastated by Moyano (e.g., Beck 2013:76-78; Hudson 1990:91), it is likely that the materials recovered from Feature 112 represent the labor of 

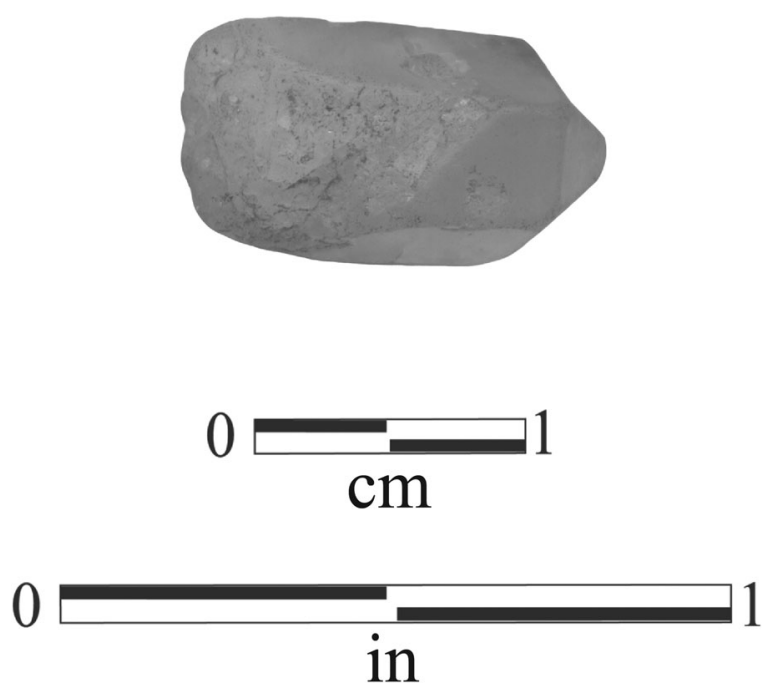

FIGURE 8. Quartz crystal from Structure 5.

Pisgah (or Chisca) women taken back to Fort San Juan from these destroyed towns (Moore et al 2016).

There is some evidence that the women preparing food in Structure 5 were also engaging in activities that Spanish soldiers may have interpreted as witchcraft. A quartz crystal (Figure 8) was recovered in the northern corner of Structure 5 , not far from the steelyard scale hook and pan. Juan de Ribas, a member of Pardo's second expedition, reported in 1600 that the soldiers of Fort San Juan collected "tiny diamonds" from veins of crystal they had discovered on a high hill near Joara, gambling for them back at the fort (Hudson 1990:163). While there are no known sources of diamond in the Carolina Piedmont, quartz is abundant and is almost certainly the mineral that Ribas described. The crystal from Structure 5 is the only such object recovered from the Spanish compound and may be among the "tiny diamonds" collected by Pardo's men.

How did one of these small crystals end up in Structure 5, a building associated with food preparation and the labor of captive Indian women? It could, perhaps, have been dropped or lost by one of the soldiers, but there is another, more interesting possibility. Indians in the American Southeast regarded quartz crystals as sources of power that could be used for divination (Hudson 1976:168). Among the Cherokee, they could also be used for conjuring a race of spirits known as the "Little People" (Mooney 1900:333334). In Myths of the Cherokee, James Mooney (1900:460) reported that "he who owns a crystal can call one of the Little People to him at any time and make him do his bidding." Thus, it is possible that one of the quartz crystals collected by Pardo's men came to be possessed by an Indian woman who labored preparing meals in this building and that the crystal is evidence of indigenous ritual practice. As I noted earlier, captive women may have been more readily coerced into domestic and sexual servitude than local women from Joara. Yet the presence of these particular captives in Structure 5-given their handling of the soldiers' food and the imagined proximity of their ruined towns to the Chichimec heartland-may have required special, apotropaic precautions.

We can return, then, to the iron jack plate fragment deposited in a posthole in Structure 5. Similar plates, and even entire coats of plate, have been recovered from other early colonial sites, including Santa Elena and Jamestown. To create a complete coat, individual iron or brass plates were sewn together between layers of canvas or fabric, creating a "jack" (outer garment) of plate. The plate from Structure 5 is one of more than two-hundred 16th-century European artifacts recovered from the Spanish compound. This Berry assemblage, although small, is unusual in the interior Southeast; while other assemblages are dominated by trade goods, especially glass beads, the Berry assemblage consists primarily of quotidian objects (Rodning et al. 2016). The classes of European material culture identified in the Berry site's assemblage include utilitarian ceramics and hardware (wrought nails and tacks), arms and armaments such as lead shot and links of chain mail (which were regularly lost from chain mail shirts or hoods), and personal goods like copper lacing tips and iron clothing fasteners. Most of these artifacts were recovered from plow zone or from secondary contexts such as refuse deposits in the central and western pits. Structures 1 and 5, for example, seem to have been cleaned out before being burned and thus yielded few artifacts in primary use contexts. Apart from the steelyard scale hook and small pan from Structure 5, the inventory of European artifacts recovered from both buildings consists of only a few glass beads, some chain mail links, and the iron jack plate.

The feature that yielded the Berry site jack plate fragment, Posthole 2, was at the southern corner of Structure 5 in its entryway (Figure 7); no one could have entered or exited the structure without passing by this post. Before considering the implications of the jack plate and its context, we should examine the range of means by which its deposition might have taken place. First, the relationship between Posthole 2 and the jack plate - the only European artifact recovered from any posthole at Berry _ could either have occurred as a result of accident or intentional deposit. There are three ways that artifacts regularly end up in a posthole by accident: (1) the posthole is dug into an existing soil context that contains artifacts, which are subsequently redeposited in the posthole fill after the post is set; (2) artifacts are dropped and lost within the posthole during the digging of the hole or the setting of the post; and, finally, (3) after a post is removed from a posthole, artifacts fall into the resulting cavity, or postmold.

We can rule out the third possibility, because the post itself was never removed (it burned in place), and the jack plate was clearly deposited in the yellow posthole fill not in the darker soil of the postmold (Figure 9). While the first and second possibilities both appear plausible (as each explains deposits in the posthole fill), I believe that they can both be ruled out as well, given the position of the armor fragment in Posthole 2. Had it been part of the existing soil context 
(a)

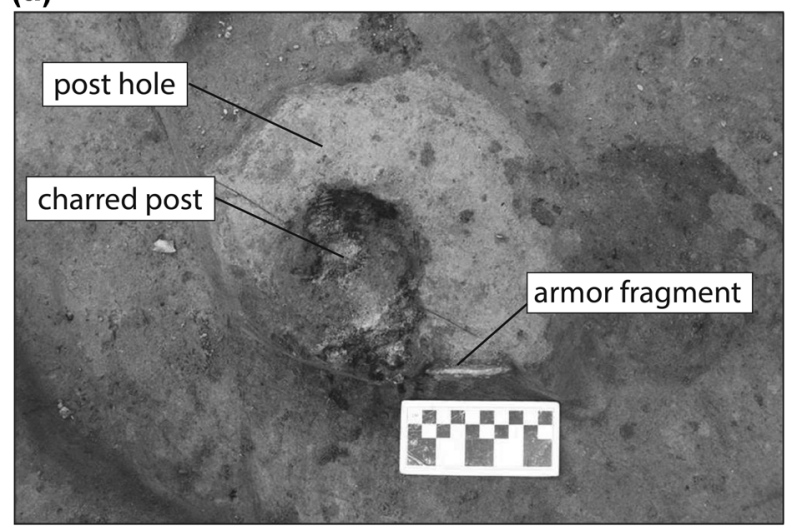

(b)

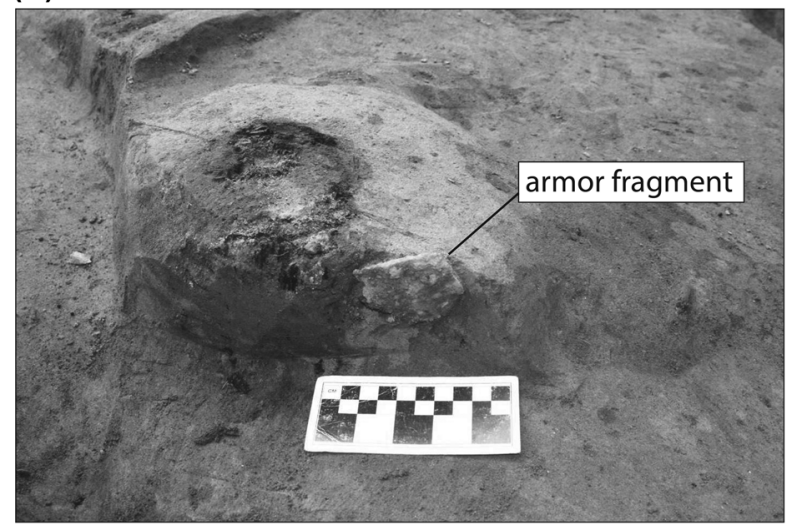

FIGURE 9. Detail of posthole, postmold, and carbonized post in Structure 5: (a) overhead view with iron jack plate fragment indicated; (b) side view.

and pushed back into the posthole fill after the post was set (scenario 1) or dropped and lost while the post was being set (scenario 2), we should expect the artifact to have come to rest oriented flat or at a random angle to the curving plane of the posthole. Instead, its orientation is perpendicular to the plane. Tightly wedged between the posthole cut and the upright post, both its position and its orientation are better explained as the result of a deliberate act. If so, then who put the iron in the posthole, and why? I believe that we can rule out native women working in and around Structure 5, whether locals from Joara or captured Chiscas. Iron was too exotic and too valuable in native exchange networks to be removed from circulation in this way. Even for the soldiers at Fort San Juan, iron was a precious resource, especially so given the uncertainties about when Pardo might return with new supplies. Yet one of these soldiers may have had a compelling reason to deposit a fragment of iron jack plate so near the doorway of the kitchen.

Europeans had long conferred apotropaic powers to iron (Bell 2012:82; Filotas 2005:263; Gallop 1936:65; Herva and Ylimaunu 2009:237; Lawrence 1896:288-292; Manning 2014b:72-73; Merrifield 1987:161-162). As early as the first century C.E., Pliny the Elder observed in his Natural History that iron gave adults and children alike protections against ensorcellment (Pliny 1961:9:237). Some magi, he records, professed that even "a whetstone on which iron tools have been often sharpened," if placed under the pillow of a person sickened by sorcery or magic, could cause the victim to identify the poison (Pliny 1961:8:35). In Sussex, southern England, large iron slabs found in entryway thresholds of 16th-century buildings have been interpreted as protection against the intrusion of witches or other supernaturals (Tebbutt 1984:240). Even iron horseshoes - still viewed today as tokens of good luck-were hung over doors as apotropaic devices, because witches were supposedly unable to cross iron (Lawrence 1896). As for Spain, Margarita Candón and Elena Bonnet write: "Era costumbre que para proteger una casa de los hechizos había que enterrar un objeto viejo de hierro cerca de la puerta" [It was customary, that to protect a house from spells, one had to bury an old iron object near the door] (1995:80, author's translation).

I suggest that the jack plate in Posthole 2 served as an apotropaic ritual device. Concealed near the door of the Spanish compound's kitchen, it offered protection against Indian women - all of whom were potential witches who might use magic to ensorcell the food they prepared within. The threat of culinary witchcraft would have been of no small concern to the soldiers stationed at Fort San Juan, encultured as they were in the potential dangers of women's labor, particularly the control that women wielded over food. At Joara, as relations between their fort and the town began to unravel, surrounded by infidel peoples so far from Christendom and so close - or so they believed - to the Chichimec, the threat must have seemed to the Spaniards as all too real. But this act of planting the iron in Structure 5 differed from the use of iron threshold slabs in Sussex. The latter objects were installed during building construction in response to a general fear of witches. The iron jack plate, however, was not a part of the building's original design, as were the large and cumbersome threshold slabs. Instead, it was probably a spontaneous or ad hoc addition to Structure 5-a manifestation, perhaps, of a particular Spaniard's specific fears. It was a personal act that reflects the personal, domestic witchcraft of Spanish belief; indeed, we might understand this device in its architectural context as a spiritual armor that protected the building and the food prepared within just as it had protected the body of the soldier who relinquished it.

The practice of apotropaic folk ritual at early Spanish colonies should not be surprising in light of Europeans' anxieties about witchcraft and the widespread belief that practices such as the deliberate concealment of mundane objects could counteract the effects of ensorcellment. What is surprising, however, is how little documentation we have for these practices in the architecture of such colonial sites. Part of the issue is the nature of the archaeology itself. Most architectural evidence for apotropaic ritual, both visible and concealed, comes from intact, standing structures. Apotropaic markings and objects were placed over and behind the vulnerable parts of a building, such as its chimneys, windows, and doors. They were hidden beneath 
the floorboards and inside the walls. Yet most early colonial sites lack standing structures, so that these folk ritual devices, even when encountered by the archaeologist, typically lack the contextual information needed to identify them as such. More often than not, we are left with but the small subset of such devices that were deliberately buried. Here the issue is recognizing the potential apotropaic significance of everyday materials recovered from unusual subsurface contexts. Apotropaic deposits have yet to be identified at other Spanish colonial sites in the Southeast, though at Santa Elena there are at least two strong candidates that resemble other examples of folk ritual practice.

Santa Elena's first significant fortification, Fort San Felipe, was constructed by Pardo and his soldiers after their arrival from Spain in July 1566. San Felipe was damaged by fire in 1570, requiring the construction of a new fort (Lyon 1984:15). This new San Felipe consisted of two strong houses (casa fuertes) that were finished in 1572. In 1983, Stanley South directed large-scale fieldwork in one of these, the other having been lost to erosion (South 1984). A narrow ditch demarcated the wall of the casa fuerte, which formed a parallelogram measuring 15 by 20 meters; 16 very large posts, set in postholes more than a meter in diameter, supported a second floor that may have held artillery (South 1996:45). Near the top of one of these features, Posthole 198, archaeologists recovered a large fragment of bordado, a coiled copper wire, with a garnet bead still attached (South 1984:39). Bordado was a kind of decorative braid usually sewn onto the clothing of high-status gentlemen, and its recovery from a posthole is reminiscent of the apotropaic use of deliberately concealed garments. Even more suggestive is the fragment of iron armor found at the top of the feature cluster 148/170/239. This group of features was associated with the emplacement and removal of a large interior support post inside the strong house (South 1984:33; South et al 1988:111, figure 63). It is impossible to know with certainty if this object, its brass buckle still attached, was deliberately placed in Feature 170 as an apotropaic device, but its clear stratigraphic association with a posthole does offer a remarkable parallel to the jack plate recovered from Posthole 2 in Structure 5 at the Berry site.

\section{CONCLUSIONS}

Small things may unlock worlds of meaning and purpose (Loren and Beaudry 2006), and so it is with the jack plate from Structure 5. The artifact itself is a mundane object (or would have been to a 16th-century Spanish soldier) that in a traditional artifact typology might simply be classified as a piece of military equipment. Yet no other artifact from the Berry site, and perhaps no other object from all the interior of La Florida, so conveys the profound sense of vulnerability and isolation experienced by would-be conquistadors unmoored in this unknown country. It also bears witness to the women who labored among strangers - whether willingly or in captivity - and to the potential potency of their labors. It can communicate these broader worlds of meaning not through anything inherent in the object itself but through the unusual or unanticipated context of its deposition. This is true of most material evidence of apotropaic folk ritual, because the secreting away of the mundane is what alerts us that all may not be as it appears. By recognizing evidence of such practice, when it exists, we glean unexpected insights into personal anxieties, values, and beliefs. We can never know the name of the Spaniard who planted the iron jack plate in Structure 5. But the social and spatial contexts of his act allow us to better understand his world during the weeks and months before the destruction of Fort San Juan.

Robin A. Beck University of Michigan, Museum of Anthropological Archaeology, Ann Arbor, MI 48103; rabeck@umich.edu; https://lsa.umich.edu/anthro/people/faculty/archaeologicalfaculty/rabeck.html

\section{NOTE}

Acknowledgments. Funding for excavations and analyses in the Berry site Spanish compound have been provided by the National Science Foundation (BCS-0542120); the National Geographic Society Committee on Research and Exploration; a National Park Service Certified Local Governments Grant to the City of Morganton, administered by the North Carolina Division of Archives and History, Department of Cultural Resources; the Burke County Historical Society; the Historic Burke Foundation; and the Woodbury Foundation. The School for Advanced Research in Santa Fe, New Mexico, hosted several project members for a 2009 Research Team Short Seminar, an opportunity that contributed greatly to our collective understanding of the Spanish compound. I would like to thank my project codirectors, David Moore and Christopher Rodning, for their generous feedback on this article. I would also like to thank John Chenoweth for first suggesting that I pursue an apotropaic interpretation of the iron jack plate in Structure 5. I thank the American Anthropologist editor-in-chief, Michael Chibnik, and seven anonymous reviewers for their comments and suggestions that have greatly improved the article. Finally, I would like to thank the Berry family for their continued stewardship of the Berry site.

\section{REFERENCES CITED}

Anderson, David G.

1994 Factional Competition and the Political Evolution of Mississippian Chiefdoms in the Southeastern United States. In Factional Competition and Political Development in the New World. Elizabeth M. Brumfiel and John W. Fox, eds. Pp. 61-76. Cambridge: Cambridge University Press.

Bandera, Juan de la

1990 Proceedings for the Account Which Captain Juan Pardo Gave of the Entrance Which He Made into the Land of the Floridas. In The Juan Pardo Expeditions: Explorations of the Carolinas and Tennessee, 1566-1568, By Charles Hudson. Paul Hoffman, trans. Pp. 255-296. Washington, DC: Smithsonian Institution Press. 
Beck, Robin A.

1997 From Joara to Chiaha: Spanish Exploration of the Appalachian Summit Area, 1540-1568. Southeastern Archaeology 16(2):162-169.

2013 Chiefdoms, Collapse, and Coalescence in the Early American South. Cambridge: Cambridge University Press.

Beck, Robin A., Jr., and David G. Moore

2002 The Burke Phase: A Mississippian Frontier in the North Carolina Foothills. Southeastern Archaeology 21(2):192-205.

Beck, Robin A., Jr., David G. Moore, and Christopher B. Rodning 2006 Identifying Fort San Juan: A Sixteenth-Century Spanish Occupation at the Berry Site, North Carolina. Southeastern Archaeology 25(1):65-77.

Beck, Robin A. David G. Moore, Christopher B. Rodning, Sarah Sherwood, and Elizabeth T. Horton

2016 The Built Environment of the Berry Site Spanish Compound. In Fort San Juan and the Limits of Empire: Colonialism and Household Practice at the Berry Site. Robin A. Beck, Christopher B. Rodning, and David G. Moore, eds. Pp. 85-149. Gainesville: University Press of Florida.

Behar, Ruth

1987 Sex and Sin, Witchcraft and the Devil in Late-Colonial Mexico. Special issue, "Frontiers of Christian Evangelism," guest edited by Jane Schneider and Shirley Lindenbaum, American Ethnologist 14(1):34-54.

1989 Sexual Witchcraft, Colonialism, and Women's Powers: Views from the Mexican Inquisition. In Sexuality and Marriage in Colonial Spanish America. Asunción Lavrin, ed. Pp. 178-206. Lincoln: University of Nebraska Press.

Bell, Karl

2012 The Magical Imagination: Magic and Modernity in Urban England, 1780-1914. Cambridge: Cambridge University Press.

Borić, Duŝan

2002 "Deep Time" Metaphor: Mnemonic and Apotropaic Practices at Lepinski Vir. Journal of Social Archaeology 3(1): 46-74.

Candón, Margarita, and Elena Bonnet

1995 Toquemos madera!: Diccionario e historia de las supersticiones españolas [Touch wood! Dictionary and history of Spanish superstitions]. Madrid: A. and M. Muchnik.

Deagan, Kathleen A.

1983 Spanish St. Augustine: The Archaeology of a Colonial Creole Community. New York: Academic.

1985 The Archaeology of Sixteenth Century St. Augustine. Florida Anthropologist 38(1-2), Part 1:6-33.

2008 Comment. Current Anthropology 49(5):877-878.

DePratter, Chester B., Charles M. Hudson, and Marvin T. Smith

1983 Juan Pardo's Explorations in the Interior Southeast, 15661568. The Florida Historical Quarterly 62:125-158.

Eastop, Dinah

2006 Context and Meaning Generation: The Conservation of Garments Deliberately Concealed within Buildings. In The Object in Context: Crossing Conservation Boundaries. David
Saunders, Joyce H. Townsend, and Sally Woodcock, eds. Pp. 17-22. London: International Institute of Conservation. 2007 Material Culture in Action: Conserving Garments Deliberately Concealed within Buildings. Anais do Museu Paulista: História e Cultura Material 15(1):187-204.

Fennell, Christopher C.

2000 Conjuring Boundaries: Inferring Past Identities from Religious Artifacts. International Journal of Historical Archaeology 4(4):281-313.

2014 Artifacts to Invoke, Direct, and Deflect. Special issue, "Manifestations of Magic: The Archaeology and Material Culture of Folk Religion," Christopher C. Fennell and M. Chris Manning, eds. Historical Archaeology 48(3):196-200.

Filotas, Bernadette

2005 Pagan Survivals, Superstitions, and Popular Cultures in Early Medieval Pastoral Literature. Toronto: Pontifical Institute of Mediaeval Studies.

Fritz, Gayle J.

2016 People, Plants, and Early Frontier Food. In Fort San Juan and the Limits of Empire: Colonialism and Household Practice at the Berry Site. Robin A. Beck, Christopher B. Rodning, and David G. Moore, eds. Pp. 237-270. Gainesville: University Press of Florida.

Gallop, Rodney

1936 Portugal: A Book of Folk-Ways. New York: Macmillan.

Gell, Alfred

1992 The Technology of Enchantment and the Enchantment of Technology. In Anthropology, Art, and Aesthetics. Jeremy Coote and Anthony Shelton, eds. Pp. 40-63. Oxford: Clarendon.

1998 Art and Agency: An Anthropological Theory. Oxford: Clarendon.

Gilchrist, Roberta

2012 Medieval Life: Archaeology and the Life Course. Woodbridge, UK: Boydell.

Hally, David J.

2008 King: The Social Archaeology of a Late Mississippian Town in Northwestern Georgia. Tuscaloosa: University of Alabama Press.

Herva, Vesa-Pekka

2009 Living (with) Things: Relational Ontology and Material Culture in Early Modern Northern Finland. Cambridge Archaeological Journal 19(3):388-397.

Herva, Vesa-Pekka, and Timo Ylimaunu

2009 Folk Beliefs, Special Deposits, and Engagement with the Environment in Early Modern Northern Finland. Journal of Anthropological Archaeology 28(2):234-243.

Hoffman, Paul E.

1990 A New Andalucia and a Way to the Orient: The American Southeast during the Sixteenth Century. Baton Rouge: Louisiana State University Press.

Hoggard, Brian

2004 The Archaeology of Counter-Witchcraft and Popular Magic. In Beyond the Witch Trials: Witchcraft and Magic in 
Enlightenment Europe. Owen Davies and Willem de Blécourt, eds. Pp. 167-186. New York: Manchester University Press. Hudson, Charles M.

1976 The Southeastern Indians. Knoxville: University of Tennessee Press.

1990 The Juan Pardo Expeditions: Explorations of the Carolinas and Tennessee, 1566-1568. Washington, DC: Smithsonian Institution Press.

Hukantaival, Sonja

2013 Finding Folk Religion: An Archaeology of "Strange" Behavior. Electronic Journal of Folklore 55:99-124.

Johgart, Abra

2011 Native American and Spanish Ancillary Structures: An Analysis of Postholes at the Berry Site. B.A. thesis, Department of Sociology and Anthropology, Warren Wilson College.

Jones, B. Calvin, and Gary Shapiro

1990 Nine Mission Sites in Apalachee. In Columbian Consequences, vol. 2: Archaeological and Historical Perspectives on the Spanish Borderlands East. David Hurst Thomas, ed. Pp. 491-509. Washington, DC: Smithsonian Institution Press.

Kramer, Heinrich, and James Springer

1948 Malleus Malleficarum. Translated with an Introduction, Bibliography and Notes by the Rev. Montague Summers. London: Pushkin.

Krögel, Allison

2011 Food, Power, and Resistance in the Andes: Exploring Quechua Verbal and Visual Narratives. Lanham: Lexington.

Lacquement, Cameron $\mathrm{H}$.

2007 Typology, Chronology, and Technological Changes of Mississippian Domestic Architecture in West-Central Alabama. In Architectural Variability in the Southeast. Cameron H. Lacquement, ed. Pp. 49-72. Tuscaloosa: University of Alabama Press.

Lapham, Heather A.

2016 Fauna, Subsistence, and Survival at Fort San Juan. In Fort San Juan and the Limits of Empire: Colonialism and Household Practice at the Berry Site. Robin A. Beck, Christopher B. Rodning, and David G. Moore, eds. Pp. 271-300. Gainesville: University Press of Florida.

Lawrence, Robert M.

1896 The Folk-Lore of the Horseshoe. The Journal of American Folklore 9(35):288-292.

Lewis, Clifford M., and Albert J. Loomie

1953 The Spanish Jesuit Mission in Virginia, 1570-1572. Chapel Hill: University of North Carolina Press.

Lewis, Laura A.

2003 Hall of Mirrors: Power, Witchcraft, and Caste in Colonial Mexico. Durham: Duke University Press.

Loren, Diana diPaolo, and Mary C. Beaudry

2006 Becoming American: Small Things Remembered. In Historical Archaeology. Martin Hall and Stephen Silliman, eds. Pp. 251-271. Oxford: Blackwell.

Lucas, Michael T.

2014 Empowered Objects: Material Expressions of Spiritual Beliefs in the Colonial Chesapeake Region. Special issue, "Manifestations of Magic: The Archaeology and Material Culture of
Folk Religion,” Christopher C. Fennell and M. Chris Manning, eds. Historical Archaeology 48(3):106-124.

Lyon, Eugene

1976 The Enterprise of Florida: Pedro Menéndez de Avilés and the Spanish Conquest of 1565-1568. Gainesville: University Press of Florida.

1984 Santa Elena: A Brief History of the Colony, 1566-1567. Columbia: University of South Carolina, South Carolina Institute of Archaeology and Anthropology, Research Manuscript Series 193.

Manning, Chris M.

2012 Homemade Magic: Concealed Deposits in Architectural Contexts in the Eastern United States. Master's thesis, Department of Anthropology, Ball State University.

2014a Magic, Religion, and Ritual in Historical Archaeology. Special issue, "Manifestations of Magic: The Archaeology and Material Culture of Folk Religion," Christopher C. Fennell and M. Chris Manning, eds. Historical Archaeology 48(3): $1-9$.

2014b The Material Culture of Ritual Concealments in the United States. Special issue, "Manifestations of Magic: The Archaeology and Material Culture of Folk Religion," Christopher C. Fennell and M. Chris Manning, eds. Historical Archaeology 48(3):52-83.

Martínez, Francisco

1990 The Martinez Relation. In The Juan Pardo Expeditions: Exploration of the Carolinas and Tennessee, 1566-1568, by Charles Hudson. Paul Hoffman, transl. Pp. 317-322. Washington, DC: Smithsonian Institution Press.

Maxwell-Stuart, P. G.

2001 Witchcraft in Europe and the New World, 1400-1800. New York: Palgrave Macmillan.

McEwan, Bonnie G.

1991 Hispanic Life on the Seventeenth-Century Florida Frontier. Special issue, “The Missions of La Florida,” Bonnie G. McEwan, ed. Florida Anthropologist 44(2-4):255-267.

Merrifield, Ralph

1987 The Archaeology of Ritual and Magic. New York: New Amsterdam.

Mooney, James

1900 Myths of the Cherokee. 19th Annual Report of the Bureau of American Ethnology. Washington, DC: Government Printing Office.

Moore, David G.

2002 Catawba Valley Mississippian: Ceramics, Chronology, and Catawba Indians. Tuscaloosa: University of Alabama Press.

Moore, David G., Robin A. Beck, and Christopher B. Rodning

2016 Native Material Culture from the Spanish Compound. In Fort San Juan and the Limits of Empire: Colonialism and Household Practice at the Berry Site. Robin A. Beck, Christopher B. Rodning, and David G. Moore, eds. Pp. 341-367. Gainesville: University Press of Florida.

Newsom, Lee A.

2016 Wood Selection and Technology in Structures 1 and 5. In Fort San Juan and the Limits of Empire: Colonialism and Household Practice at the Berry Site. Robin A. Beck, 
Christopher B. Rodning, and David G. Moore, eds. Pp. 150232. Gainesville: University Press of Florida.

Osborne, Robin

2004 Hordes, Votives, Offerings: The Archaeology of the Dedicated Object. World Archaeology 36(1):1-10.

Pliny the Elder

1961 Natural History. Harris Rackham, trans. Cambridge: Harvard University Press.

Rodning, Christopher B., Robin A. Beck, David G. Moore, and James Legg

2016 Spanish Material Culture from the Berry Site. In Fort San Juan and the Limits of Empire: Colonialism and Household Practice at the Berry Site. Robin A. Beck, Christopher B. Rodning, and David G. Moore, eds. Pp. 303-340. Gainesville: University Press of Florida.

Ruppel, Timothy, Jessica Neuwirth, Mark P. Leone, and GladysMarie Fry

2003 Hidden in View: African Spiritual Spaces in North American Landscapes. Antiquity 77(296):321-335.

Saunders, Rebecca

1991 Architecture of the Missions Santa María and Santa Catalina de Amelia. Special issue, "The Missions of La Florida," Bonnie G. McEwan, eds. Florida Anthropologist 44(2-4):126-138.

Silverblatt, Irene

1987 Moon, Sun, and Witches: Gender Ideologies and Class in Inca and Colonial Peru. Princeton: Princeton University Press.

South, Stanley A.

1984 Testing Archeological Sampling Methods at Fort San Felipe 1983. Research Manuscript Series, 190. Columbia: South Carolina Institute of Archeology and Anthropology, University of South Carolina.

1996 Archaeology at Santa Elena: Doorway to the Past. Popular Series 2. Columbia: South Carolina Institute of Archaeology and Anthropology.
South, Stanley A., Russell Skowronek, and Richard Johnson 1988 Spanish Artifacts from Santa Elena. Anthropological Studies, 7. Columbia: South Carolina Institute of Archaeology and Anthropology.

Tebbutt, C. F.

1980 Iron Thresholds as a Protection. Folklore 91(2):240.

Thomas, David Hurst

1991 The Archaeology of Mission Santa Catalina de Guale: Our First Fifteen Years. Special issue, "The Missions of La Florida," Bonnie G. McEwan, ed. Florida Anthropologist 44(2-4):107125.

Voss, Barbara L.

2008 Gender, Race, and Labor in the Archaeology of the Spanish Colonial Americas. Current Anthropology 49(5):861-893.

Walker, William H.

1998 Where Are the Witches of Prehistory? Journal of Archaeological Method and Theory 5(3):245-308.

2008 Practice and the Afterlife Histories of Witches and Dogs. In Memory Work: Archaeologies of Material Practices. Barbara M. Mills and William Walker, eds. Pp. 137-158. Santa Fe: School of American Research Press.

Walker, William H., and Lisa J. Lucero

2000 The Depositional History of Ritual and Power. In Agency in Archaeology. Marcia-Anne Dobres and John E. Robb, eds. Pp. 130-147. London: Routledge.

Weisman, Brent R.

1992 Excavations on the Franciscan Frontier: Archaeology at the Fig Springs Mission. Gainesville: University Press of Florida.

Worth, John E.

2016 Recollections of the Juan Pardo Expeditions: The Domingo De León Account. In Fort San Juan and the Limits of Empire: Colonialism and Household Practice at the Berry Site. Robin A. Beck, Christopher B. Rodning, and David G. Moore, eds. Pp. 58-80. Gainesville: University Press of Florida. 